\title{
Comparative Study of Analysis and Design of Pre-Engineered- Buildings and Conventional Frames
}

\author{
Aijaz Ahmad Zende ${ }^{1}$, Prof. A. V. Kulkarni ${ }^{2}$, Aslam Hutagi ${ }^{\mathrm{a}}$ \\ ${ }^{1}$ MTech Studenst, ${ }^{2}$ Professor, Civil Engg Dept,B.L.D.E.A's College of Engineering and Technology, India.
}

ABSTRACT : Long Span, Column free structures are the most essential in any type of industrial structures and Pre Engineered Buildings (PEB) fulfill this requirement along with reduced time and cost as compared to conventional structures. The present work involves the comparative study of static and dynamic analysis and design of Pre Engineered Buildings (PEB) and Conventional steel frames. Design of the structure is being done in Staad Pro software and the same is then compared with conventional type, in terms of weight which in turn reduces the cost. Three examples have been taken for the study. Comparison of Pre Engineered Buildings (PEB) and Conventional steel frames is done in two examples and in the third example, longer span Pre Engineered Building structure is taken for the study. In the present work, Pre Engineered Buildings (PEB) and Conventional steel frames structure is designed for dynamic forces, which includes wind forces and seismic forces. Wind analysis has been done manually as per IS 875 (Part III) - 1987 and seismic analysis has been carried out as per IS 1893 (2002).

Keywords: Pre-Engineered-Buildings; Staad Pro; Utilization Ratio; Tapered Sections.

\section{INTRODUCTION}

Steel industry is growing rapidly in almost all the parts of the world. The use of steel structures is not only economical but also eco friendly at the time when there is a threat of global warming. Here, "economical" word is stated considering time and cost. Time being the most important aspect, steel structures (Pre fabricated) is built in very short period and one such example is Pre Engineered Buildings (PEB). Pre engineered buildings are nothing but steel buildings in which excess steel is avoided by tapering the sections as per the bending moment's requirement. One may think about its possibility, but it's a fact many people are not aware about Pre Engineered Buildings. If we go for regular steel structures, time frame will be more, and also cost will be more, and both together i.e. time and cost, makes it uneconomical. Thus in pre engineered buildings, the total design is done in the factory, and as per the design, members are pre fabricated and then transported to the site where they are erected in a time less than 6 to 8 weeks.

The structural performance of these buildings is well understood and, for the most part, adequate code provisions are currently in place to ensure satisfactory behavior in high winds [1]. Steel structures also have much better strength-to-weight ratios than RCC and they also can be easily dismantled. Pre Engineered Buildings have bolted connections and hence can also be reused after dismantling. Thus, pre engineered buildings can be shifted and/or expanded as per the requirements in future. In this paper we will discuss the various advantages of pre engineered buildings and also, with the help of three examples, a comparison will be made between pre engineered buildings and conventional steel structures.

\subsection{Pre Engineered Buildings}

Presently, large column free area is the utmost requirement for any type of industry and with the advent of computer softwares it is now easily possible.

With the improvement in technology, computer softwares have contributed immensely to the enhancement of quality of life through new researches. Pre-engineered building (PEB) is one of such revolution. "Pre-engineered buildings" are fully fabricated in the factory after designing, then transported to the site in completely knocked down (CKD) condition and all components are assembled and erected with nut-bolts, thereby reducing the time of completion. 


\subsubsection{Advantages of PEB}

Following are some of the advantages Pre-engineered building structures-

a) Construction Time: Buildings are generally constructed in just 6 to 8 weeks after approval of drawings. PEB will thus reduce total construction time of the project by at least $40 \%$. This allows faster occupancy and earlier realization of revenue.

This is one of the main advantages of using Pre-engineered building.

b) Lower Cost: Because of systems approach, considerable saving is achieved in design, manufacturing and erection cost.

c) Flexibility of Expansion: As discussed earlier, these can be easily expanded in length by adding additional bays. Also expansion in width and height is possible by pre designing for future expansion.

d) Large Clear Spans: Buildings can be supplied to around $90 \mathrm{~m}$ clear spans. This is one of the most important advantages of PEB giving column free space.

e) Quality Control: Buildings are manufactured completely in the factory under controlled conditions, and hence the quality can be assured.

f) Low Maintenance: PEB Buildings have high quality paint systems for cladding and steel to suit ambient conditions at the site, which in turn gives long durability and low maintenance coats.

g) Energy Efficient Roofing: Buildings are supplied with polyurethane insulated panels or fiberglass blankets insulation to achieve required "U" values (overall heat transfer coefficient).

h) Erection: Steel members are brought to site in CKD conditions, thereby avoiding cutting and welding at site. As PEB sections are lighter in weight, the small members can be very easily assembled, bolted and raised with the help of cranes. This allows very fast construction and reduces wastage and labor requirement.

From the numerous advantages of Pre-engineered building, in the present study, the points $b$ and $d$ are considered for the study, i.e. to save the steel, reducing cost and providing large clear spans, while all the other points are self explanatory.

\section{Analysis and Design of PEB}

In this present work, Staad Pro software has been used in order to analyze and design Pre-engineered building structures and conventional structures. In the first example, a 3D model of a Hostel building has been designed and compared with conventional structure using conventional steel. In the second example, a 2D plane frame of width $44 \mathrm{~m}$ for both PEB and conventional has been designed and comparison has been made in terms of weight of steel. In the third example, a 2D plane frame of width $88 \mathrm{~m}$ has been designed with tapered sections for PEB, this example is not solved with conventional sections as it is neither possible by using only conventional steel sections nor it is economical. This frame has been designed for different bay spacing to choose the most economical.

\subsection{Pre-Engineered Buildings by Staad Pro}

The power tool for computerized structural engineering STAAD Pro is the most popular structural engineering software product for 3D model generation, analysis and multi-material design. It has an intuitive, user-friendly, visualization tools, powerful analysis and design facilities and seamless integration to several other modeling and design software products. The software is fully compatible with all Windows operating systems.

For static or dynamic analysis of Pre-engineered building, STAAD Pro has been the choice of design professionals around the world for their specific analysis needs. [2] 


\subsection{Structural Analysis and Design}

STAAD Pro software can be used for analyzing and designing of the pre-engineered buildings. It gives the Bending Moment, Axial Forces, Shear Forces, Torsion, Beam Stresses of a steel structure so that the design can be done using tapered sections and check for the safety.

\subsubsection{Static Analysis}

In the present work, using the Staad Pro software, 2D/3D analysis has been done using Stiffness Matrix Method. All the components of Pre-engineered building are tapered using the in-built option of the Software. The software provides options for hinged, fixed, and spring supports with releases so as to analyze as per our requirement. Herein this work, fixed supports are assigned to the structures. It also facilitates Linear, P-Delta Analysis, and Non-Linear Analysis with automatic load and stiffness correction. Multiple Analyses can also be done simultaneously which reduces the time. It also has an option of assigning members as tension-only members and compression-only members for truss structures.

\subsubsection{Dynamic Analysis}

Dynamic analysis has been done in the present work taking seismic loads and wind loads into consideration. The software provides automatic load generation for seismic and wind forces, however, the seismic loads and wind loads are calculated manually for the present work as per IS codes. The software also provides Loading for Joints, Members/Elements including Concentrated, Uniform, Linear, Trapezoidal, Temperature, Strain, Support Displacement, Prestressed and Fixed-end Loads. It also provides the facility of Combination of Dynamic forces with Static loading for subsequent design.

\section{Example 1- Hostel Building}

\subsection{Statement of the Problem}

In the first example of this study, a Hostel building of $14.37 \mathrm{~m} \mathrm{X} 52.14 \mathrm{~m}$ has been analyzed and designed with bay spacing at $8.4 \mathrm{~m}$. The eave height is taken as $6 \mathrm{~m}$ with a roof slope of 1 in 10 . The Plan of the building is shown in Fig 1.

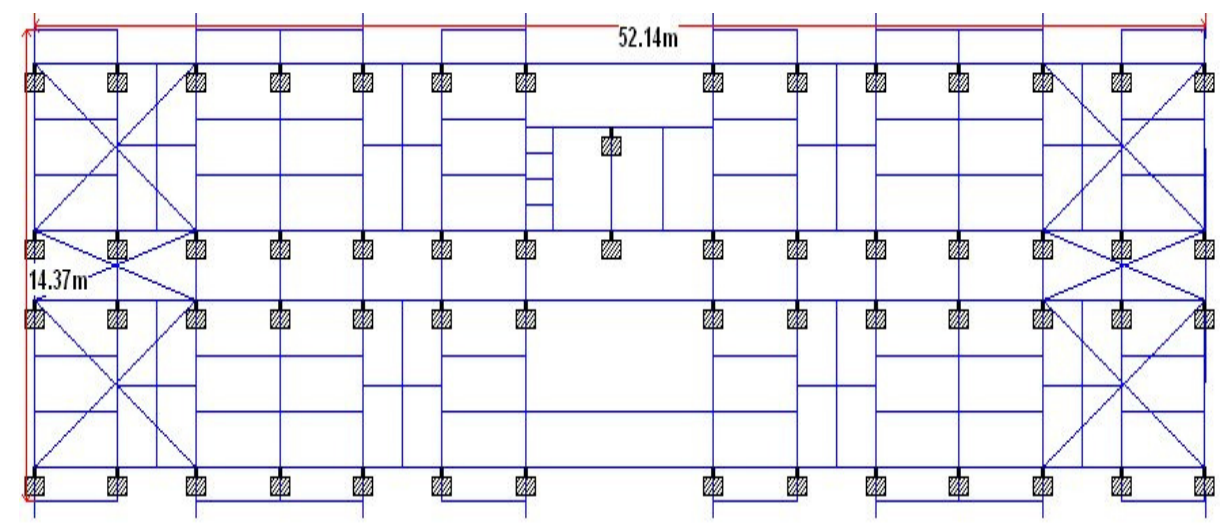

Figure 1- Plan of the Building

\section{Design Data-}

Main Frame-

Frame Type- Clear Span, Rigid Frame.

Support- Pinned

Building Width (W) - 14.37m (O/O Steel Columns)

Building Length (L) - 52.14m (O/O Steel Columns) 
Bay Spacing- $6 @ 8.4 \mathrm{~m}$

Eaves height- $8.39 \mathrm{~m}$

Roof Slope- 1 in 10

Grits Type

Sidewall grits- Continuous

Endwall grits- Continuous

Purlin Type-

Roof Purlin- Continuous

Spacing- $1.5 \mathrm{~m} \mathrm{c/c}$

Panel Type- Roof- Galvalume sheet

\title{
3.2 Loading
}

\subsubsection{Calculation of Static Loads}

Live loads are considered as per IS 875-1987 (Part II). [3]

i. Balcony- $4 \mathrm{kN} / \mathrm{m}^{2}$

ii. Staircase- $5 \mathrm{kN} / \mathrm{m}^{2}$

iii. Live load on floor- $2 \mathrm{kN} / \mathrm{m}^{2}$

iv. Toilet- $3 \mathrm{kN} / \mathrm{m}^{2}$

v. Water Tank- $40 \mathrm{kN}$

Dead Loads

\author{
i. Slab Weight- $2.5 \mathrm{kN} / \mathrm{m}^{2}$ \\ ii. Floor Finish- $1 \mathrm{kN} / \mathrm{m}^{2}$ \\ iii. Pardi- $2.5 \mathrm{kN} / \mathrm{m}^{2}$ \\ iv. Sheet Load + Insulation- $1.072 \mathrm{kN} / \mathrm{m}^{2}$
}

\subsubsection{Calculation of Seismic Loads}

When an earthquake occurs, vibrations are produced in the ground near the surface that creates inertia forces and movements in the structure. The magnitude of this force is directly proportional to the dead load of the structure. Metal building systems, due to their low dead load, do not usually have their design governed by seismic forces and hence, in the present work, the seismic load doesn't govern the design and the most critical load is found to be wind load. However, for seismic analysis, following data has been used as per IS 1893 Part I2002. [4]

Zone V

Response reduction factor-4 (For Steel frames with concentric braces)

Importance factor, I, is taken as 1.5 , though it is 1 as per IS code, to be on safer side.

Damping ratio- 3 (For Steel Buildings)

Soil type- II

Time period in $\mathrm{X}$ and $\mathrm{Y}$ directions-

$$
\mathrm{Tx}=0.085 \mathrm{H}^{3} / 4
$$

Time period in both directions- $0.4677 \mathrm{Sec}$

Therefore, $\mathrm{Sa} / \mathrm{g}=1.250$,

Horizontal Seismic Co-efficient, Ah, $\mathrm{Ah}=0.08437$

Therefore, Base Shear, Vb,

$$
\begin{aligned}
\mathrm{Vb} & =\mathrm{Ah} \times \mathrm{W} \\
& =7063 \mathrm{kN} .
\end{aligned}
$$




\subsubsection{Calculation of Wind Loads}

Wind loads are calculated as per IS 875 Part II (1987) [5], in this example. For the Present work, the basic wind speed $(\mathrm{Vb})$ is assumed as $50 \mathrm{~m} / \mathrm{s}$ and the building is considered to be open terrain with well scattered obstructions having height less than $10 \mathrm{~m}$ with maximum dimension more than $50 \mathrm{~m}$ and accordingly factors $\mathrm{K} 1$, K2, K3 have been calculated as per IS 875 Part II (1987).

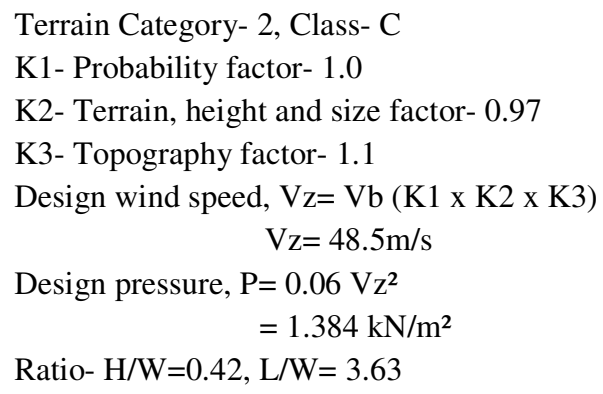

\section{Wind Pressure Coefficients-}

External and Internal wind coefficients are calculated for all the surfaces for both pressure and suction. Opening in the building has been considered less than 5\% and accordingly internal coefficients are taken as +0.5 and -0.5 . The external coefficients and internal coefficients calculated as per IS 875 Part II (1987).

Wind load on individual members are then calculated as below.

$$
\mathrm{F}=(\mathrm{Cpe}-\mathrm{Cpi}) \times \mathrm{A} \times \mathrm{P}
$$

Where, Cpe, Cpi are external coefficients and internal coefficients respectively and A and P are Surface Area in $\mathrm{m}^{2}$ and Design Wind Pressure in $\mathrm{kN} / \mathrm{m}^{2}$ respectively.

\subsection{Load Combinations}

For the present work, various primary loads that are considered are given below-

$\begin{array}{lll}\text { 1. } & \text { Primary } & \text { DEAD LOAD } \\ \text { 2. } & \text { Primary } & \text { LIVE LOAD } \\ \text { 3. } & \text { Primary } & \text { ROOF LIVE } \\ \text { 4. } & \text { Primary } & \text { WIND 1 A } \\ \text { 5. } & \text { Primary } & \text { EQX 1 } \\ \text { 6. } & \text { Primary } & \text { EQZ 1 } \\ \text { 7. } & \text { Primary } & \text { WIND 1 B } \\ \text { 8. } & \text { Primary } & \text { WIND 2 A } \\ \text { 9. } & \text { Primary } & \text { WIND 2 B }\end{array}$

For the Primary loads considered for the study, following are the Load Combinations taken for Hostel Building.

$\begin{array}{ll}\text { Combination } & 1 \\ \text { Combination } & 2 \\ \text { Combination } & 3 \\ \text { Combination } & 4 \\ \text { Combination } & 5 \\ \text { Combination } & 6 \\ \text { Combination } & 7 \\ \text { Combination } & 8 \\ \text { Combination } & 9 \\ \text { Combination } & 10 \\ \text { Combination } & 11\end{array}$

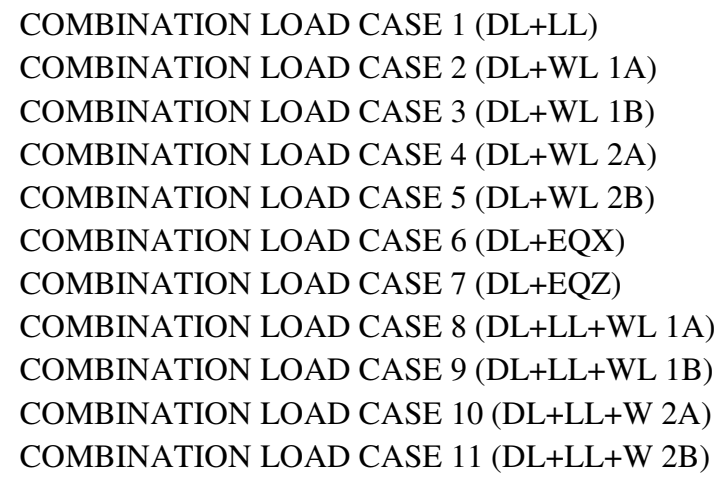


Comparative Study of Analysis and Design of Pre-Engineered-Buildings and Conventional Frames

$\begin{array}{lll}\text { Combination } & 12 & \text { COMBINATION LOAD CASE } 12 \text { (DL+LL+EQX) } \\ \text { Combination } & 13 & \text { COMBINATION LOAD CASE } 13 \text { (DL+LL+EQZ) }\end{array}$

Table 1 gives the guiding load cases $(\mathrm{L} / \mathrm{C})$ for individual members for which the design has been carried out.

Table 1-Member End Forces

\begin{tabular}{|c|c|c|c|c|c|c|c|c|}
\hline \multirow{2}{*}{ Forces } & \multirow{2}{*}{ Beam } & \multirow{2}{*}{ L/C } & Axial & \multicolumn{2}{|c|}{ Shear } & \multicolumn{2}{c|}{ Torsion } & \multicolumn{2}{c|}{ Bending } \\
\cline { 4 - 9 } & & $\begin{array}{c}\mathbf{F x} \\
\mathbf{k N}\end{array}$ & $\begin{array}{c}\mathbf{F y} \\
\mathbf{k N}\end{array}$ & $\begin{array}{c}\mathbf{F z} \\
\mathbf{k N}\end{array}$ & $\begin{array}{c}\text { Mx } \\
\mathbf{k N}-\mathbf{m}\end{array}$ & $\begin{array}{c}\text { My } \\
\mathbf{k N}-\mathbf{m}\end{array}$ & $\begin{array}{c}\text { Mz } \\
\mathbf{k N}-\mathbf{m}\end{array}$ \\
\hline Max Fx & 17 & $\begin{array}{c}\text { Combination } \\
\text { load case 10 }\end{array}$ & 511.43 & 4.51 & -16.23 & 0.126 & -3.36 & 2.02 \\
\hline Min Fx & 46 & 4 Wind 1 A & -102.26 & 1.76 & -15.48 & -0.043 & 32.46 & 8.44 \\
\hline Max Fy & 96 & $\begin{array}{c}\text { Combination } \\
\text { load case 10 }\end{array}$ & 17.74 & 111.45 & -0.048 & -0.002 & 0.11 & 37.41 \\
\hline Min Fy & 321 & $\begin{array}{l}\text { Combination } \\
\text { load case 10 }\end{array}$ & 1964 & -180.72 & 0.537 & -0.02 & 0.17 & 147.82 \\
\hline Max Fz & 164 & $\begin{array}{l}\text { Combination } \\
\text { load case 13 }\end{array}$ & 143.44 & 8.94 & 60.21 & -1.289 & -79.59 & 7.51 \\
\hline Min Fz & 412 & $\begin{array}{l}\text { Combination } \\
\text { load case 11 }\end{array}$ & 207.21 & -6.3 & -61.63 & -0.11 & 68.4 & -0.8 \\
\hline Max Mx & 415 & $\begin{array}{l}\text { Combination } \\
\text { load case 15 }\end{array}$ & 25.32 & 98.62 & -0.29 & 34.91 & 0.3 & 89.86 \\
\hline Min Mx & 442 & $\begin{array}{l}\text { Combination } \\
\text { load case 11 }\end{array}$ & 15.28 & -63.96 & 0.16 & -34.02 & 0.11 & -46.85 \\
\hline Max My & 565 & 7 Wind 1 B & 0.388 & -0.063 & 60.91 & 0.38 & 124.8 & 0.045 \\
\hline Min My & 581 & $\begin{array}{l}\text { Combination } \\
\text { load case 13 }\end{array}$ & 214.50 & 1.719 & 50.74 & -0.15 & -100.02 & 16.07 \\
\hline Max Mz & 661 & $\begin{array}{l}\text { Combination } \\
\text { load case 15 }\end{array}$ & 216.85 & 32.54 & 1.4 & 0.58 & -0.677 & 151.74 \\
\hline Min Mz & 658 & $\begin{array}{l}\text { Combination } \\
\text { load case 10 }\end{array}$ & 17.76 & 70.82 & 0.087 & 0.1 & 0.091 & -151.43 \\
\hline
\end{tabular}

\subsection{Results for Hostel Building}

The results obtained after analyzing and designing Pre Engineered Building and Conventional Building were significant. Table 1 shows the Member End Forces of some of the members for maximum and minimum Axial, Shear, Torsion and Bending. Column 1 in this table shows the maximum and minimum forces and moments in $\mathrm{x}, \mathrm{y}$, and $\mathrm{z}$ directions. Column 2 shows some of the member numbers, and $\mathrm{L} / \mathrm{C}$ is the guiding load case for the respective member. Column 4, 5, 6 are the axial and shear forces and 7, 8, 9 are the torsion and bending moments for the respective members. Fig 2 illustrates this table. 


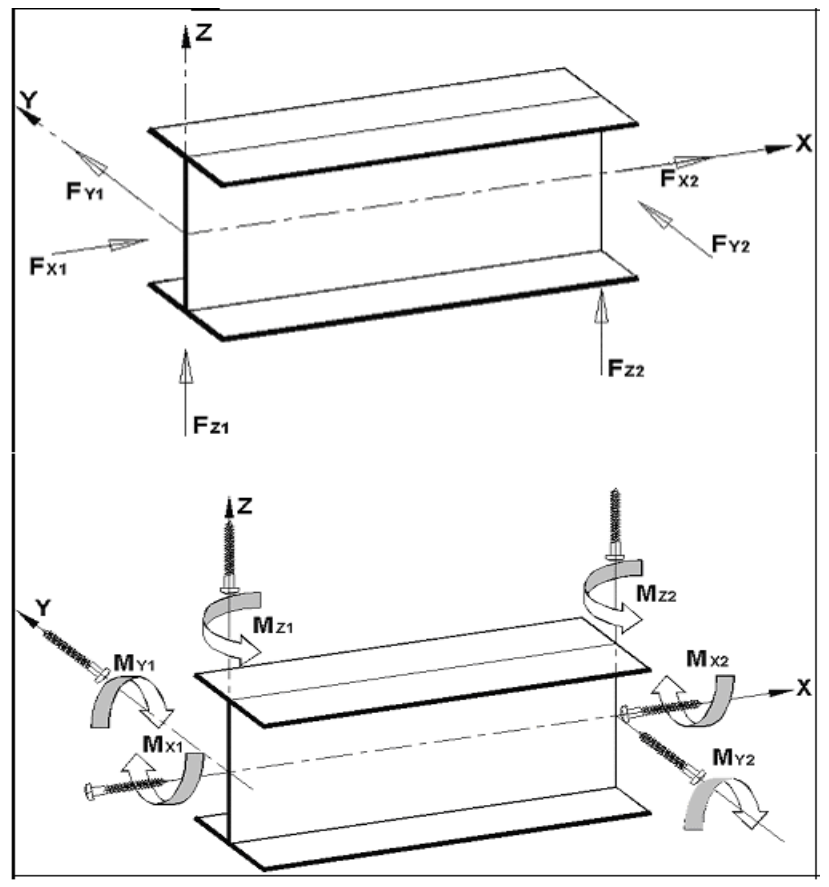

Figure 2 Member end forces

\subsubsection{Column Design Results}

The steel columns were rested over concrete columns and the design sample of one of the column.

Grade- M20

Steel- Fe415

Length: $2450.0 \mathrm{~mm}$

Cross Section: $500.0 \mathrm{~mm} \mathrm{X} 800.0 \mathrm{~mm}$ with Cover: $40.0 \mathrm{~mm}$

Guiding load case: 4

Reqd. Steel area : $644.40 \mathrm{~mm}^{2}$.

Reqd. Concrete area: $80550.45 .61 \mathrm{~mm}^{2}$.

Main reinforcement: Provide 12\# - 12 dia. (0.34\%, $1357.17 \mathrm{~mm}^{2}$.) (Equally distributed)

Tie reinforcement: Provide $8 \mathrm{~mm}$ dia. rectangular ties @ $190 \mathrm{~mm} \mathrm{c} / \mathrm{c}$.

\subsubsection{Design Utilization ratio}

Utilization ratio is the critical value that indicates the suitability of the member as per IS 875 (LSD). Normally, a value higher than 1.0 indicates the extent to which the member is over-stressed, and a value below 1.0 tells us the reserve capacity available. Critical conditions used as criteria to determine Pass/Fail status are slenderness limits, Axial Compression and Bending, Axial Tension and Bending, Maximum w/t ratios and Shear. Fig 3 shows the screenshot taken from staad pro software showing utilization ratio for some of members. In this table, Column 1 shows the member numbers, Column 2 and 3 shows the details of members with their sizes. Column 4, 5, 6 shows the actual, allowable and their ratio which must be less than 1 . Column 7 shows the IS Code clauses for which the members are subjected. Column 8 shows the guiding load case for the respective member. Column 9, 10,11, 12 are the cross sectional properties of the respective members. 
Comparative Study of Analysis and Design of Pre-Engineered-Buildings and Conventional Frames

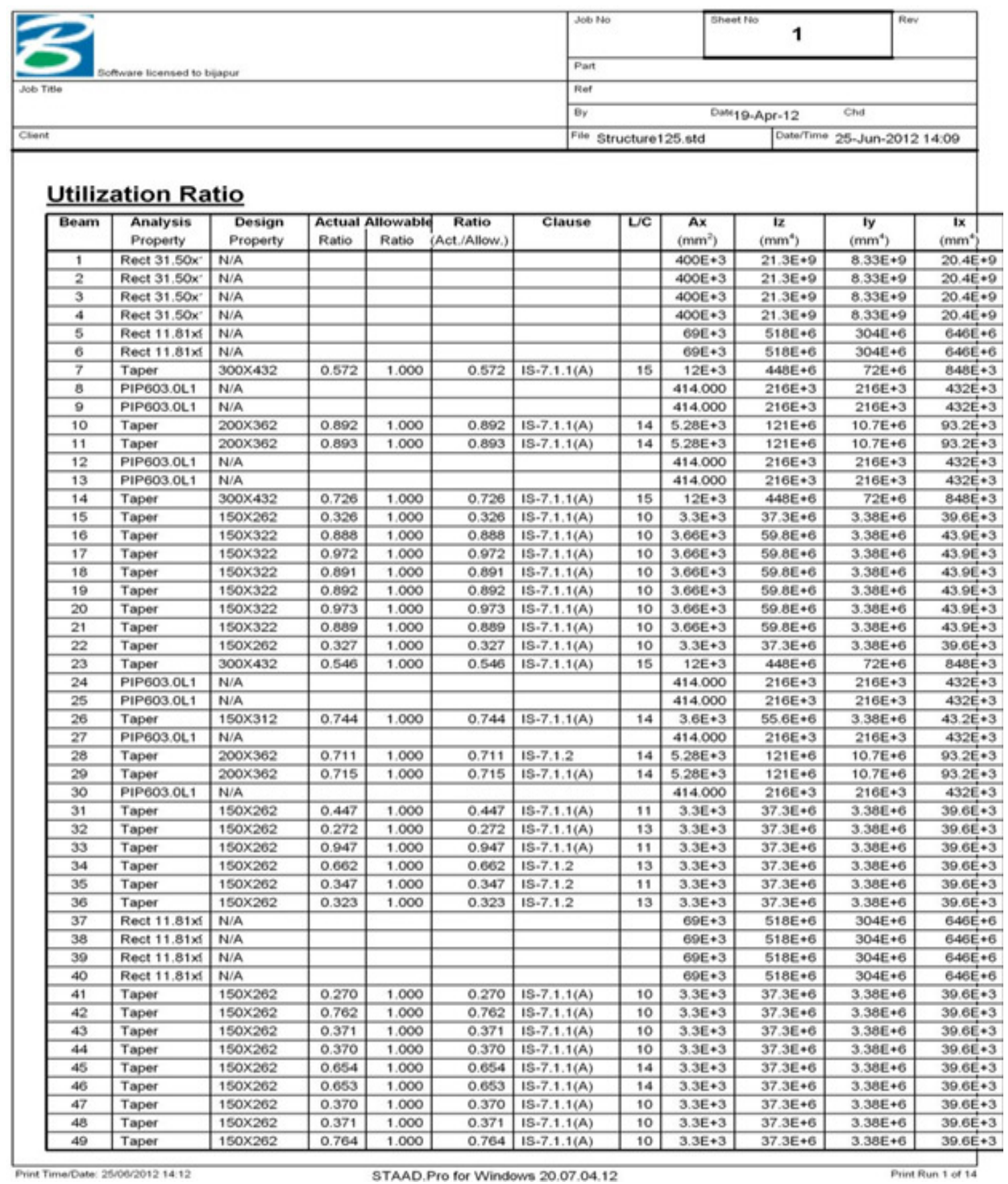

Figure 3- Screenshot of Utilization Ratio for various members from Stadd Pro Software

\subsection{Weight of Steel (Steel Take-Off)}

The weight of PEB and conventional building is calculated after the design. For PEB, the weight of sections is given in Table 2. In this table, column 1 shows the profile of members with same cross sectional properties. Sizes of members are given in column 2, a typical I- Section for Tapered Member No 3 is shown in Fig 4. 
Column 3 shows the overall length of members with same cross sectional properties. Column 4 shows the weight of section calculated with density of $76.81 \mathrm{kN} / \mathrm{m}^{3}$.

Table 2- Steel Take-Off for Hostel PEB Buildings

\begin{tabular}{|c|c|c|c|}
\hline PROFILE & Size (mm) & LENGTH (m) & WEIGHT $(\mathbf{k N})$ \\
\hline Tapered Member No: 1 & $300 \times 432$ & 108.53 & 100.043 \\
\hline Tapered Member No: 2 & $200 \times 362$ & 28.32 & 11.47 \\
\hline Tapered Member No: 3 & $150 \times 262$ & 284.2 & 73.47 \\
\hline Tapered Member No: 4 & $150 \times 322$ & 20.36 & 5.84 \\
\hline Tapered Member No: 5 & $150 \times 312$ & 81.59 & 23.01 \\
\hline Tapered Member No: 6 & $300 \times 428$ & 30 & 25.38 \\
\hline Tapered Member No: 7 & $200 \times 312$ & 109.12 & 35.9 \\
\hline Tapered Member No: 8 & $200 \times 362$ & 48.04 & 16.93 \\
\hline Tapered Member No: 9 & $220 \times 326$ & 40.72 & 17.16 \\
\hline Tapered Member No: 10 & $280 \times 436$ & 12 & 12.76 \\
\hline Tapered Member No: 11 & $220 \times 312$ & 13.05 & 5.41 \\
\hline Tapered Member No: 12 & $300 \times 436$ & 6 & 6.20 \\
\hline Tapered Member No: 13 & $340 \times 436$ & 9 & 10.32 \\
\hline Tapered Member No: 14 & $220 \times 486$ & 5.09 & 2.53 \\
\hline Tapered Member No: 15 & $180 \times 312$ & 10.18 & 3.16 \\
\hline Tapered Member No: 16 & $240 \times 382$ & 12.93 & 6.11 \\
\hline Tapered Member No: 17 & $220 \times 500$ & 3.85 & 1.94 \\
\hline Tapered Member No: 18 & $360 \times 440$ & 3 & 4.14 \\
\hline Tapered Member No: 19 & $200 \times 412$ & 8.39 & 3.15 \\
\hline Tapered Member No: 20 & $240 \times 412$ & 5.09 & 2.11 \\
\hline \multicolumn{3}{|c|}{ Total } & 369.24 \\
\hline
\end{tabular}

Similarly Table 3 gives the weight of conventional building designed by conventional sections in which column 1 shows the standard sections and column 2 shows the overall length. Column 3 shows the calculated weight of sections. 
Comparative Study of Analysis and Design of Pre-Engineered-Buildings and Conventional Frames

Table 3- Steel Take-Off for Hostel Conventional Buildings

\begin{tabular}{|c|c|c|}
\hline PROFILE & Length (m) & Weight (KN ) \\
\hline FR ISMC300 & 308.27 & 220.42 \\
\hline FR ISMC200 & 302.59 & 133.73 \\
\hline FR ISMC250 & 206.27 & 124.96 \\
\hline FR ISMC350 & 10.18 & 3.56 \\
\hline FR ISMC150 & 12.14 & $\mathbf{4 9 1 . 6 4}$ \\
\hline
\end{tabular}

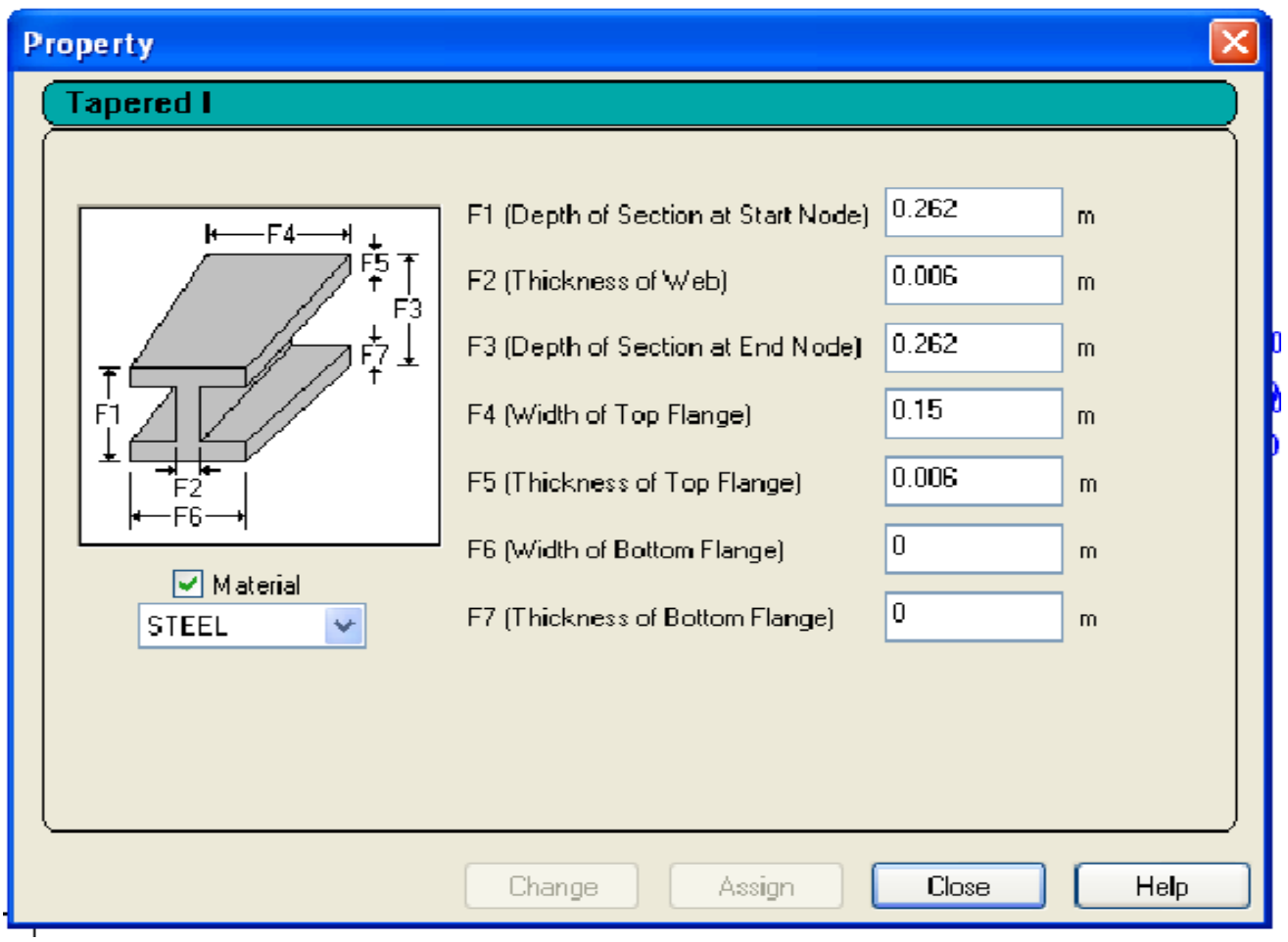

Figure 4 Tapered I Section

It is seen that the weight of tapered PEB sections are $369.24 \mathrm{kN}$ whereas for conventional building, it is found to be $491.64 \mathrm{kN}$.

Pre Engineered Building weighs $25 \%$ less than that of conventional building. 


\section{Example2- Comparison of 2D Plane Frame}

In order to know the difference further, a comparison of 2D Plane Frame is made for both pre engineered building and conventional type. The plane frame is having width $44 \mathrm{~m}$ and bay spacing $8 \mathrm{~m}$ and eave height $20 \mathrm{~m}$, subjected to wind load and seismic load. A typical 2D PEB frame is shown in Fig 5 and the conventional frame as shown in Fig 6.

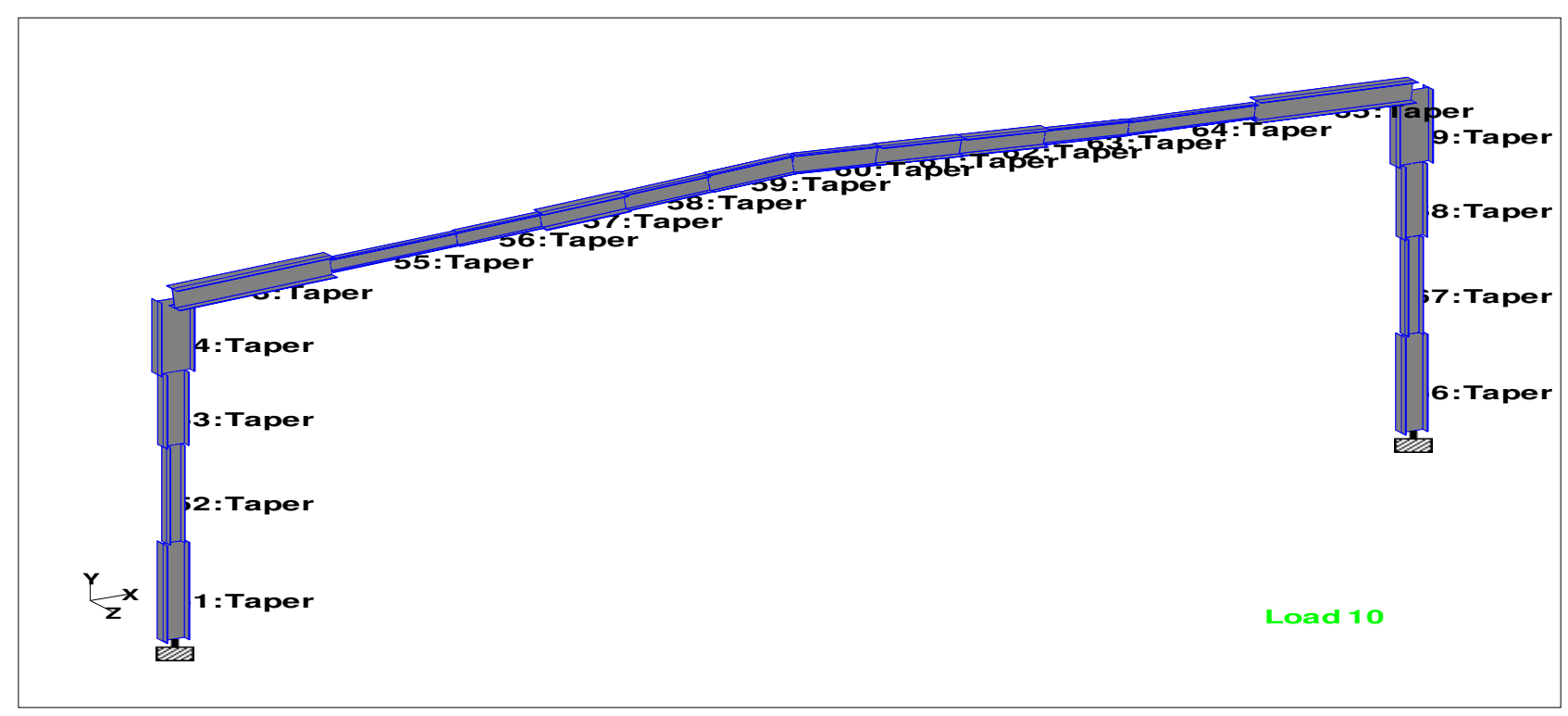

Figure 5- 2D Plane Frame of PEB

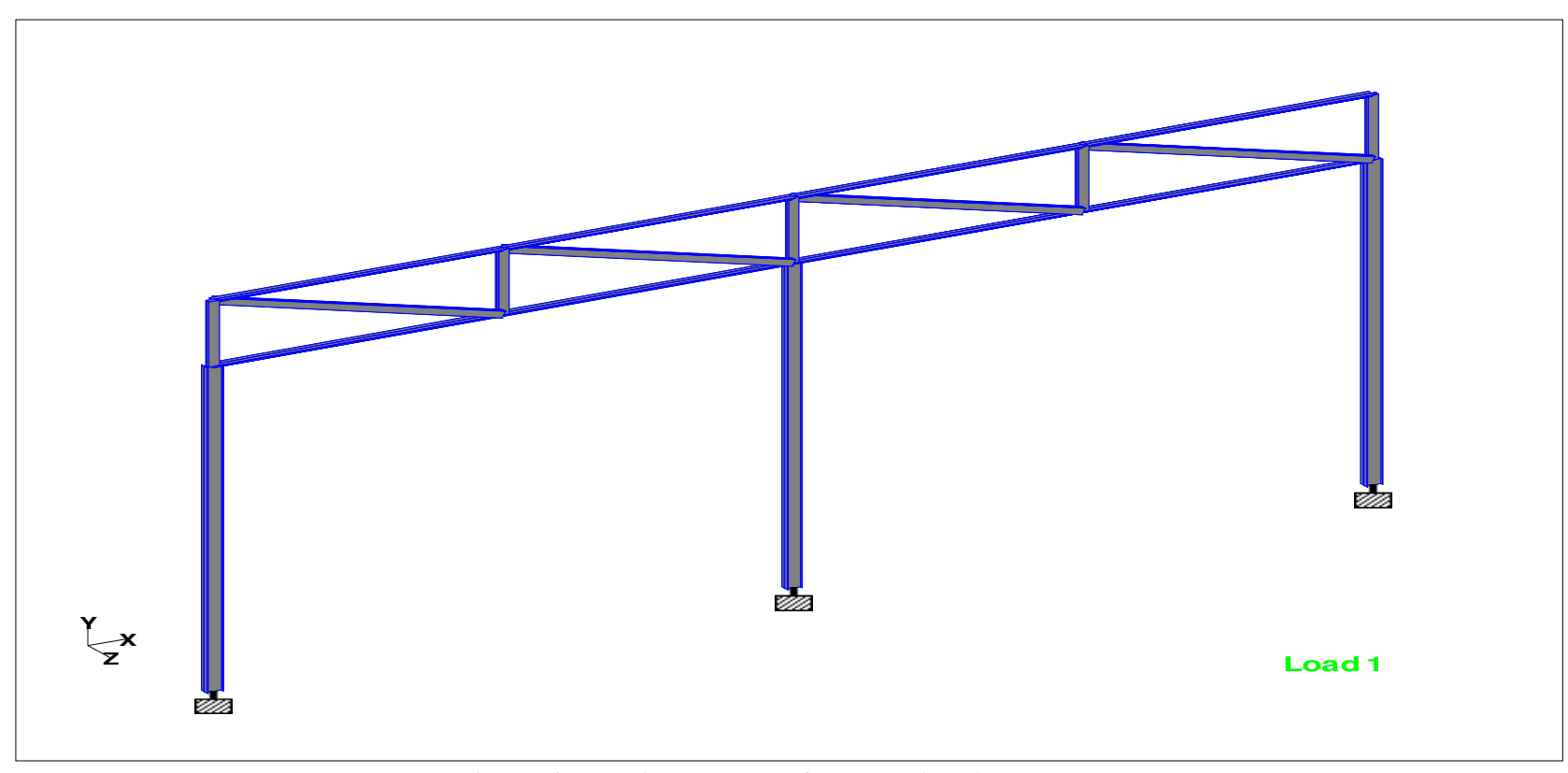

Figure 6- 2D Plane Frame of Conventional Frame 


\subsection{Loadings}

In this example, Static loads i.e., Dead loads and Live load are considered as per IS 875 (Part II) - 1987 and Dynamic loads i.e. Seismic loads and Wind loads are considered as per IS 1893 Part I (2002) and IS 875 (Part III) - 1987 respectively.

\subsubsection{Static loads- (As per IS 875 (Part II)) - 1987}

Calculation of Dead Load

$$
\begin{aligned}
& \text { Dead load }=0.10 \mathrm{kN} / \mathrm{m}^{2} \\
& \text { Bay spacing }=8 \mathrm{~m} \\
& \text { DL per met }=0.8 \mathrm{kN} / \mathrm{m}
\end{aligned}
$$

Calculation of Live Load

$$
\begin{aligned}
& \text { Live Load }=2.5 \mathrm{kN} / \mathrm{m}^{2} \\
& \text { Bay spacing }=8 \mathrm{~m} \\
& \text { LL per met }=20 \mathrm{kN} / \mathrm{m}
\end{aligned}
$$

\subsubsection{Calculation of Seismic Loads- As Per IS 1893-2002}

Following data has been considered for calculation of seismic loads-

\section{Zone II}

Response Reduction Factor- 4

Importance factor, I, is considered as 1.75

Damping ratio- 3

Time period in both directions- $0.95141 \mathrm{Sec}$

Therefore, $\mathrm{Sa} / \mathrm{g}=2.457$
$\begin{gathered}\text { Horizontal Seismic Co-efficient, } \mathrm{Ah}= \\ \mathrm{Ah}=0.0860\end{gathered}$

Therefore, Base Shear, Vb, $\mathrm{Vb}=\mathrm{Ah} \times \mathrm{W}=83 \mathrm{kN}$.

\subsubsection{Calculation of Wind Loads- As Per IS 875 (PartIII) - 1987}

For the calculation of wind loads following data have been taken.

Max Bay Spacing: 8m with Roof Slope: $5.71^{\circ}$

Location for Wind/Seismic: Bangalore $\mathrm{Vb}=33 \mathrm{~m} / \mathrm{s}$.

In this example, building is considered to be open terrain with well scattered obstructions having height less than $10 \mathrm{~m}$ with maximum dimension more than $50 \mathrm{~m}$ and accordingly factors $\mathrm{K} 1, \mathrm{~K} 2, \mathrm{~K} 3$ have been calculated as per IS 875 Part II (1987).

Terrain Category-

Class-

K1- Probability factor-

K2- Terrain, height and size factor-

K3- Topography factor-

Design Wind Speed

$\mathrm{Vz}=(\mathrm{K} 1 \mathrm{XK} 2 \mathrm{XK} 3) \mathrm{X} \mathrm{Vb}$

Design Wind Pressure, $P$,

$$
\mathrm{P}=0.6(\mathrm{Vz})^{2}=0.62 \mathrm{kN} / \mathrm{m}^{2}
$$

\section{Wind Coefficients-}

External and Internal wind coefficients are calculated for all the surfaces for both pressure and suction. Opening in the building has been considered $0 \%$ and accordingly internal coefficients are taken as +0.2 and -0.2 . 


\section{Pressure-}

Internal Wind Coefficient: -0.2; [Openings: 0\%]

External Wind Coefficient: $(0.7,-0.94,-0.4$, and -0.20$)$

Overall Wind Coefficient: $(0.5,-1.14,-0.6,-0.40)$

\section{Wind normal}

Left wall: $0.5 \times 0.62 \times 8=2.48 \mathrm{kN} / \mathrm{m}$

Right wall: $-0.40 \times 0.62 \times 8=-2 \mathrm{kN} / \mathrm{m}$

Left roof: $-1.14 \times 0.62 \times 8=-5.66 \mathrm{kN} / \mathrm{m}$

Right roof: -0.4 x $0.62 \times 8=-1.98 \mathrm{kN} / \mathrm{m}$
Wind parallel

Left wall $-0.7 *(0.62 \times 8)=-3.48 \mathrm{kN} / \mathrm{m}$

Right wall $-0.7 *(0.62 \times 8)=-3.48 \mathrm{kN} / \mathrm{m}$

Left roof $-1 *(0.62 \times 8)=-4.96 \mathrm{kN} / \mathrm{m}$

Right roof $-1 *(0.62 \times 8)=-4.96 \mathrm{kN} / \mathrm{m}$

\section{Suction-}

Internal Wind Coefficient: 0.2; [Openings: 0\%]

External Wind Coefficient: $(0.7,-0.94,-0.4$, and -0.20$)$

Overall Wind Coefficient: $(0.9,-0.74,-0.2,-0.00)$

\section{Wind normal}

Left Wall: 0.9 × $0.62 \times 8=4.47 \mathrm{kN} / \mathrm{m}$

Right Wall: $-0.0 \times 0.62 \times 8=0 \mathrm{kN} / \mathrm{m}$

Left Roof: -0.74 x $0.62 \times 8=-3.68 \mathrm{kN} / \mathrm{m}$

Right Roof: $-0.2 \times 0.62 \times 8=-1 \mathrm{kN} / \mathrm{m}$

\section{Wind parallel}

Left Wall $-0.3^{*}(0.62 \times 8)=-1.499 \mathrm{kN} / \mathrm{m}$

Right Wall $-0.3 *(0.62 \times 8)=-1.499 \mathrm{kN} / \mathrm{m}$

Left Roof $-0.6 *(0.62 \times 8)=-2.98 \mathrm{kN} / \mathrm{m}$

Right Roof $-0.6 *(0.62 \times 8)=-2.98 \mathrm{kN} / \mathrm{m}$

Fig 7 shows the calculated Wind load co-efficients for both pressure and suction.

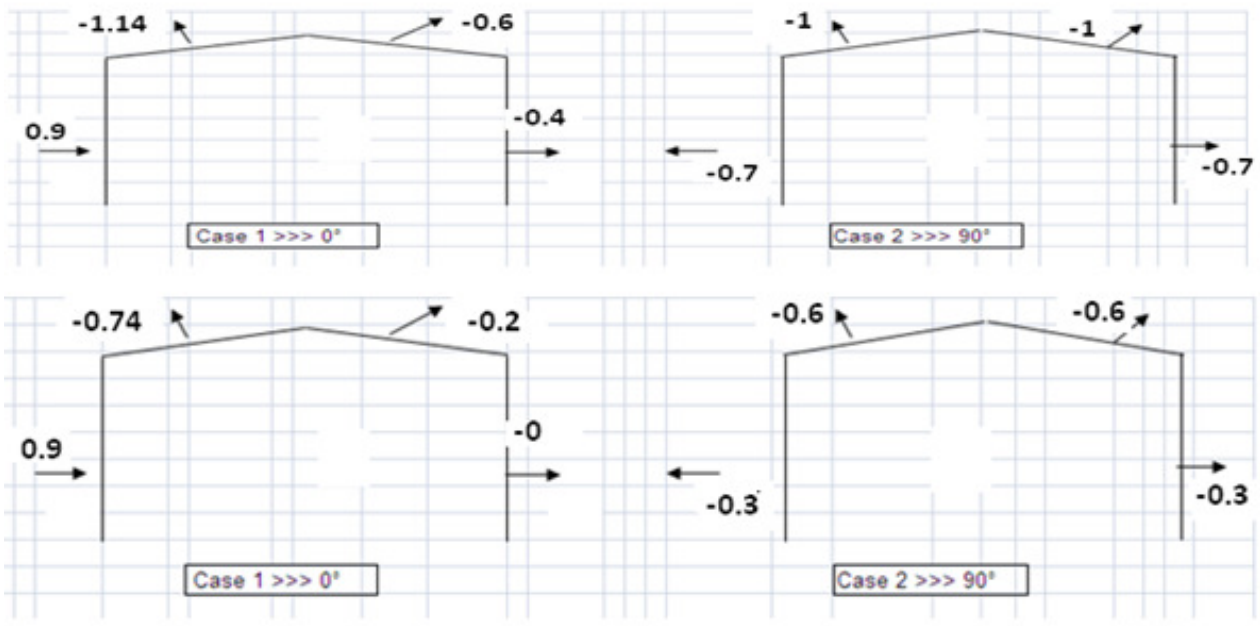

Figure 7- Wind Coefficients

\subsection{Weight of Steel (Steel Take Off)}

The Weight of PEB and conventional frame is calculated after the design. Table 4 gives the weight of plane frame conventional building. In these tables column 1 shows the sections used, LD indicates long leg back to back, double angle and FR indicates double channel front to front. Column 2 shows the overall length of the members and column 3 shows the calculated weight. 
Similarly Table 5 gives the weight of plane frame pre engineered building in which column 1 consists of members of same cross sectional properties grouped separately and designated as Tapered Member No. Column 2 and column 3 shows the sizes of the members and their length.

As it seen in the Fig 5 and Fig 6, PEB structure is designed for a clear span of 44m without any column in between, as not in case of conventional frame, where it is not possible to provide a clear span truss and hence an interior column is provided. The conventional frame is designed using Lattice truss, which is generally used for long span trusses. Results of both PEB and Conventional buildings are tabulated in Table 4 and Table 5 respectively. It can be noticed that, even though PEB structures provides clear span, it weighs $10 \%$ lesser than that of conventional buildings.

Table 4- Steel Take- Off for Plane Frame Conventional Building

\begin{tabular}{|c|c|c|}
\hline Profile & Length (m) & Weight (kN) \\
\hline LD ISA200X200X18 & 88.00 & 93.06 \\
\hline FR ISMC400 & 66.82 & 64.61 \\
\hline $\begin{array}{c}\text { PRISMATIC STEEL } \\
\text { (ISMB 600 D and ISMB 550 D) }\end{array}$ & 60.00 & 136.62 \\
\hline \multicolumn{2}{|r|}{ TOTAL } & $\mathbf{2 9 4 . 2 9}$ \\
\hline
\end{tabular}

Table 5- Steel Take- Off for Plane Frame PEB

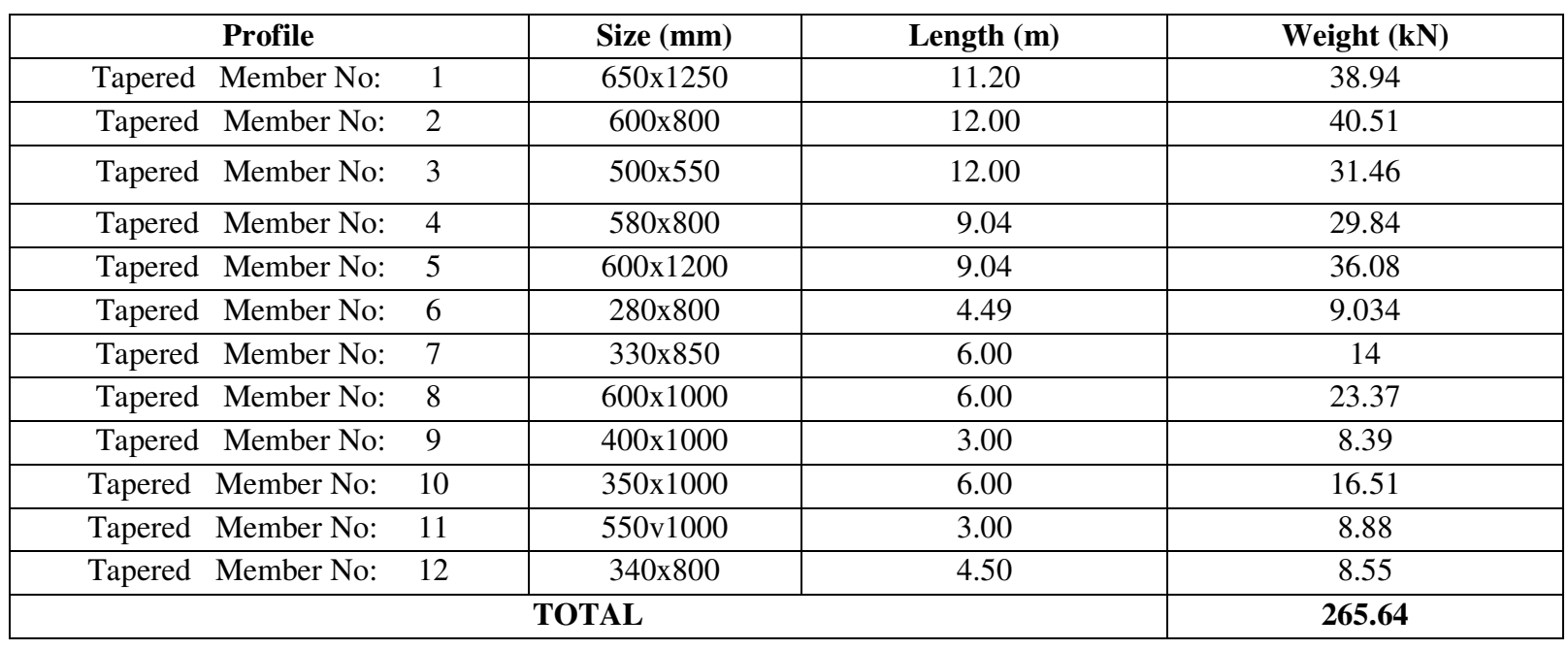

\section{Example 3- Long Span Plane Frame (PEB)}

One of the primary advantages of Pre engineered building is that it provides a clear span for spans up to even $90 \mathrm{~m}$ without any interior columns in between. In conventional buildings, it is not possible to design a structure with clear spans for large spans. In this present work, a large span plane frame for an industrial building is designed for different bay spacing- $8 \mathrm{~m}, 8.88 \mathrm{~m}, 10 \mathrm{~m}, 11.425 \mathrm{~m}, 13.33 \mathrm{~m}$ and the weights of each one is checked to know the most economical one. Fig.8 shows a typical PEB plane frame in 2D. 


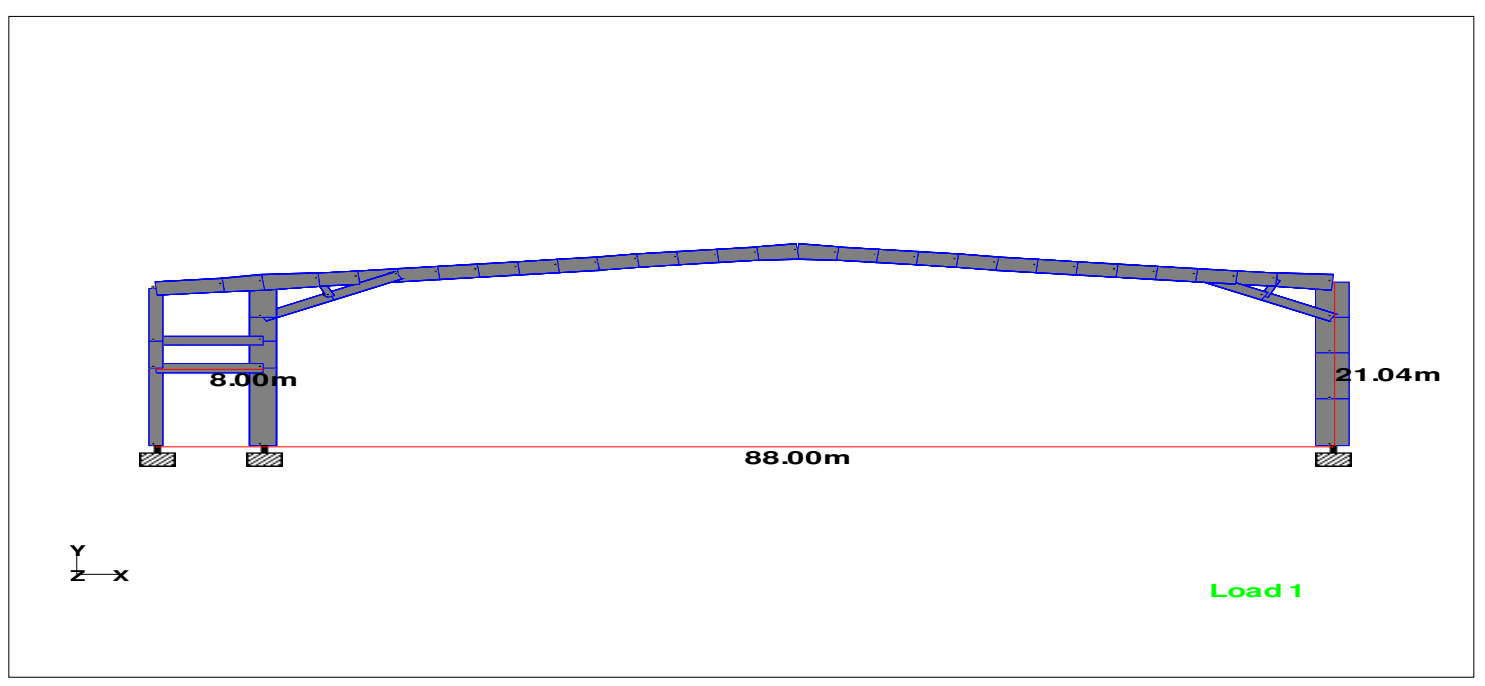

Figure 8- Long Span PEB Plane Frame

\subsection{Loadings:}

All loads are calculated as given in Section 4.1.

\subsection{Results:}

Large and clear spans allow housing almost any type and/or business comfortably and efficiently, as well as to expand in future and change their setup whenever they desire. Structures with long span need to be carefully designed keeping a balance of all the aspects like its weight, deflections (sway) and also foundation forces. There are many combinations of designing large spans, like conventional truss \& RCC column combination, truss \& steel columns, Pre-engineered building (PEB) etc.

With the concept of PEB, the major advantage we get is the use of high strength steel plates (Fe 350), lighter but high strength cold form purlins, and $550 \mathrm{Mpa}$ Galvalume profiled sheets. The use of PEB not only reduces the weight of the structure because high tensile steel grades are used but also ensures quality control of the structure.

In the present study, comparison has been made for different bay spacing considering the length of building as $80 \mathrm{~m}$ and the weights calculated for different bay spacing are given in the Table 6 . In this table, column 1 shows the different spacing for a length of $80 \mathrm{~m}$. Column 2 shows the number of frames and column 3 shows the calculated weight for each plane frame of respective spacing. Then the total weight is calculated by multiplying the weight per frame by number of frames. The total weight of the sections calculated is shown in column 4 .

Table 6- Weights for different Bay spacing

\begin{tabular}{|c|c|c|c|}
\hline $\begin{array}{c}\text { Spacing } \\
(\mathbf{m})\end{array}$ & No of Frames & $\begin{array}{c}\text { Weight/ frame } \\
(\mathbf{k N})\end{array}$ & $\begin{array}{c}\text { Total } \\
(\mathbf{k N})\end{array}$ \\
\hline 8 & 11 & 782 & 8602 \\
\hline 8.88 & 10 & 805 & 8050 \\
\hline 10 & 9 & 948 & 8537 \\
\hline 11.425 & 8 & 1046 & 8374 \\
\hline 13.33 & 7 & 1218 & 8528 \\
\hline
\end{tabular}




\section{Comparative Study of Analysis and Design of Pre-Engineered-Buildings and Conventional Frames}

It can be seen that, for an industrial building of $88 \mathrm{~m} \mathrm{X} 80 \mathrm{~m}$, the bay spacing of $8.88 \mathrm{~m}$ gives the least weight followed by bay spacing of $11.485 \mathrm{~m}$ where as the bay spacing of $8 \mathrm{~m}$ gives the highest weight.

\section{CONCLUSION}

Pre-engineered steel structures building offers low cost, strength, durability, design flexibility, adaptability and recyclability. Steel is the basic material that is used in the materials that are used for Pre-engineered steel building. It negates from regional sources. Infinitely recyclable, steel is the material that reflects the imperatives of sustainable development.

As it is seen in the present work, the weight of steel can be reduced to $27 \%$ for the hostel building, providing lesser dead load which in turn offers higher resistance to seismic forces.

Comparison in the second example showed that even though PEB structures provides clear span, it weighs 10\% lesser than that of Conventional Buildings.

For longer span structures, Conventional buildings are not suitable with clear spans. Pre-engineered building are the best solution for longer span structures without any interior column in between as seen in this present work, an industrial structure has been designed for $88 \mathrm{~m}$. With the advent of computerization, the design possibilities became almost limitless. Saving of material on low stress area of the primary framing members makes Preengineered buildings more economical than Conventional steel buildings especially for low rise buildings spanning up to 90.0 meters with eave heights up to 30.0 meters. PEB structures are found to be costly as compared to Conventional structures in case of smaller span structures.

It is also seen that the weight of PEB depends on the Bay Spacing, with the increase in Bay Spacing up to certain spacing, the weight reduces and further increase makes the weight heavier.

To Conclude "Pre-Engineered Building Construction gives the end users a much more economical and better solution for long span structures where large column free areas are needed".

\section{REFERENCES}

[1] Dale C. Perry, Herbert S. Saffir, James R. McDonald, "Performance of Metal Buildings in High Winds", Journal of Wind Engineering and Industrial Aerodynamics, 36 (1990) 985-999 985, Elsevier Science Publishers.

[2] Syed Firoz, Sarath Chandra Kumar B, S.Kanakambara Rao," Design Concept of Pre Engineered Building”, IJERA Vol. 2, Issue 2,MarApr 2012, pp.267-272 http://www.ijera.com/papers/Vol2_issue2/AS22267272.pdf

[3] IS 875- Part II (1987), Indian Standard Code of Practice for Design Loads (Other Than Earthquake) for Buildings and Structures.

[4] IS 1893- Part I (2002) Indian Standard Criteria for Earthquake Resistant of Design of Structures.

[5] IS 875- Part III (1987), Indian Standard Code of Practice for Design Loads (Other Than Earthquake) for Buildings and Structures. 